\title{
The Photoreceptor Cell of the Pineal Organ of Ayu, Plecoglossus altivelis*
}

\author{
Yuri OMURA, ** Junzoh KitoH*** and Mikio OGURI** \\ (Received September 10, 1969)
}

Since the work of DODT ${ }^{1 !}$, attention has been directed to the photosensory function of the pineal organ of fish. This function is also indicated by recent electron microscopic studies using some kinds of fish ${ }^{2-5}$.

In Ayu, light is known as the most important environmental factor in maturation of gonad $^{6)}$. In the fish the photosensitivity of the pineal organ was confirmed electrophysiologically ${ }^{7,8)}$. In the previous paper ${ }^{9}$, we described the light microscopic structure of the pineal organ of Ayu. The present paper deals with the fine structure of pineal receptor cell in Ayu, with special reference to photosensory function.

\section{Materials and Methods}

Fifteen adult specimens of cultivated Ayu, Plecoglossus altivelis were used. These fish were about $20 \mathrm{~cm}$ in body length and obtained in July and August, 1968.

The pineal organs of these fish were fixed for 1.5 to 2.0 hours in the following fixatives adjusted at $\mathrm{pH}$ 7.4: $1 \% \mathrm{OsO}_{4}$ in MILLONIG's ${ }^{10)}$ and SöRENSEN's phosphate buffer solutions or $1.3 \% \mathrm{OsO}_{4}$ in s-collidine buffer one ${ }^{11}$. After dehydration with increasing ethanol series, they were imbedded in Epoxy resin ${ }^{12}$. Thick and thin sections were made on Porter-Blum MT-1 microtome. Thick sections were stained with toluidine blue $^{13 !}$ for light microscopy. Thin sections were stained with uranyl acetate ${ }^{14}$-lead citrate $^{{ }^{5} \text { ? }}$ and observed with Hitachi HU-11A type electron microscope.

\section{Results and Discussion}

The pineal organ of Ayu has a wide lumen (pineal lumen) in the central portion and pseudostratified epithelium of the organ is divided into many folds. Under light microscopy, the cytoplasmic process protruding into the lumen was detected occasionally ${ }^{9 /}$. This process seems to correspond to the inner and outer segments of photoreceptor cell in electron microscopy. In the thick sections, small round processes covered with caplike structure were detected along the edge of fold. (Fig. 1) This cap-like structure

* This investigation was supported by a research grant of the Ministry of Education.

** Fisheries Laboratory, Faculty of Agriculture, Nagoya University, Chikusa, Nagoya, Japan. （大村

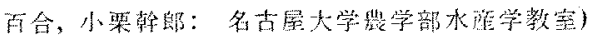

*** Department of Anatomy, Nagoya University School of Medicine, Nagoya, Japan. (鬼嘼純三: 名古屋大学医学部解剖学教室) 


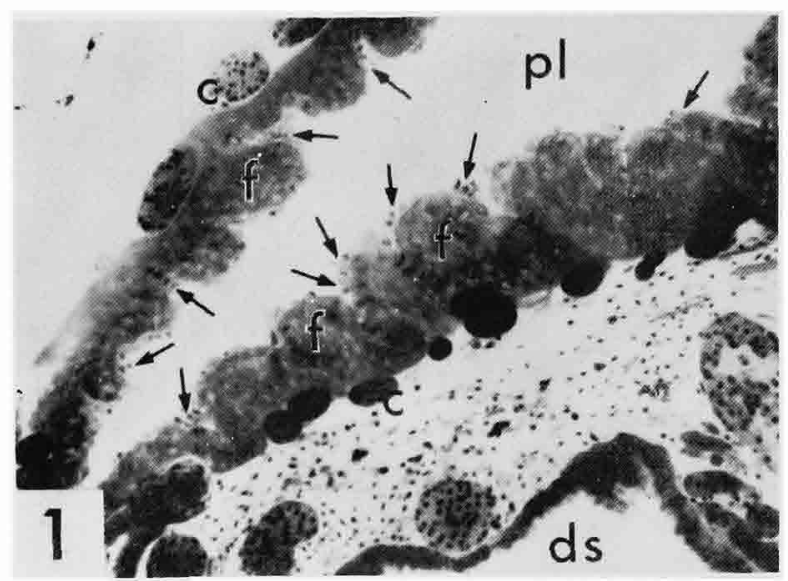

Fig. 1. Sagittal section of Ayu pineal organ. c: capillary ds: dorsal sac f: fold pl: pineal lumen Arrows show cytroplasmic processes covered with cap-like structure. $1 \% \mathrm{OsO}_{4}$ in MilloniG's phosphate buffer, $\times \mathbf{4 8 0}$.

Fig. 2. Outer and inner segments of pineal photoreceptor cell. bb: basal body $\mathrm{c}$ : centriole cf: ciliary filament is: segment $\mathrm{m}$ : mitochondria os: outer segmeet $\mathrm{pl}$ : pineal lumen $1 \% \mathrm{OsO}_{4}$ in Millonig's phosphate bufier, $\times 6,000$.

Fig. 3. A part of neuropile. bp: basal process $f$ : filament $\mathrm{m}$ : mitochondria Arrows show synaptic ribbons. $1 \% \mathrm{OsO}_{4}$ in Millonig's phosphate buffer. $\times 8,600$. Rectangle $\mathrm{A}$ is seen in the enlarged inset. $\times 17,200$. 


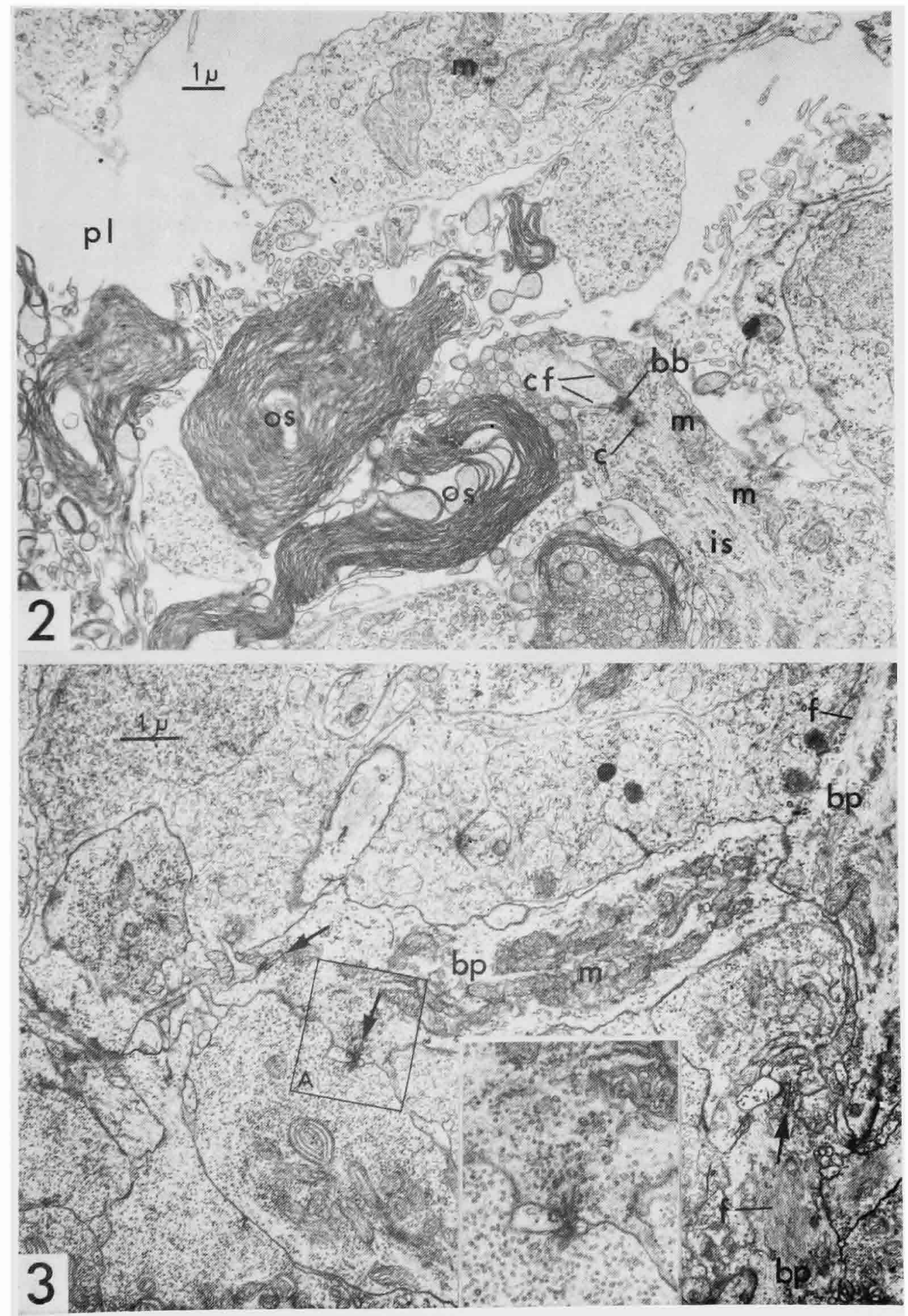


was detected more often in the narrow space between folds than in the lumenal side. This structure was stained clearly with toluidine blue.

Fig. 2 shows the lamellar structure of photoreceptor cell of Ayu. This structure seems to correspond to the cap-like structure stainable with toluidine blue in thick section. The lamellae of photoreceptor cell of Ayu were remarkably irregular in arrangement. Some of them look like whorl, and some parts are modified to the tubules or vesicles. Regular arrangement of lamellae is known in the retinal rod and cone cells ${ }^{10)}$. In the pineal receptor cell of Ayu, most of lamellae seem to be continuous with the plasma membrane. According to NILSSON ${ }^{17}$, lamellae of retinal cone cells are continuous with the plasma membrane, whereas those of rod cells are not continuous with that membrane. Accordingly, the outer segment of the pineal receptor cell of Ayu is regarded as cone type. On the structure of lamellae, further detailed investigation is being carried out.

Inner segment of receptor cell contains a basal body and a centriole near the basal region of connecting cilium. Mitochondria in the inner segment are variable in form and their cristae are irregular in arrangement. The formation of ellipsoid as seen in retinal cone and rod cells was not observed in the photoreceptor cell of the pineal organ.

As described in the previous paper ${ }^{9}$, the central region of pineal epithelial fold was stained with eosin in faint color in the preparation of MAYER's acid haemalum-eosin stain. However, clarification of detailed structure was awaited until the electron microscopic investigation. From the present observation, it was ascertained that this region consisted of basal processes of receptor cells, and of neural and glial processes. Furthermore, many synapses were found in this region. Consequently, this region was identified as "neuropile"18?.

Fig. 3 shows a part of neuropile. The basal process of receptor cell contains numerous mitochondria, and bundles of filaments running parallel with the longitudinal axis. Numerous synaptic vesicles and one or sometimes two synaptic ribbons were detected in the terminal region of basal process near the synapse. In this photograph, synaptic ribbons are seen in several places near the plasma membrane contacting with other processes. The terminal region containing numerous synaptic vesicles and the other one devoid of these vesicles seem to belong to basal process of receptor cell and distal region of dendrite, respectively.

According to MissotTEN ${ }^{19}$, cone pedicle has several synapses, whereas rod spherule has one synapse. Therefore, the basal process of the pineal receptor cell of Ayu seems to be cone pedicle type in most cases.

HanyU, Niwa and TAmURA ${ }^{7,8)}$ found the photosensitivity in the pineal organ of Ayu using electrophysiological method. Namely, they recorded spontaneous spike discharge inhibited by illumination and a slow potential similar to S-potential of the fish retina. The spontaneous spike discharge is said to be characteristic of the pineal ganglion 
cell. We have not yet observed typical ganglion cell. But the pineal tract was detected in the previous study ${ }^{9}$. Moreover, in the present investigation we found well-developed lamellar structure in outer segment of photoreceptor cell. Also synaptic region was observed in the basal process of the receptor cell. These ultrastructures indicate the photosensory function of the pineal organ of Ayu.

\section{Summary}

Electron microscopic observations were made on the pineal organ of Ayu, Plecoglossus altivelis, and the following results were obtained.

1. Well-developed lamellar structure was detected in the outer segment of photoreceptor cell protruding into the pineal lumen. This lamellar structure was remarkably irregular in comparison with that of retinal rod and cone cells.

2. In so-called "neuropile", many basal processes of the photoreceptor cells were found. Several synaptic regions were detected in these processes.

These results indicate the photosensory function of the pineal organ of Ayu.

We wish to express our cordial thanks to Prof. T. TAmura, Faculty of Agriculture, Nagoya University and Dr. I. Hanyu, Faculty of Agriculture, the University of Tokyo, for their valuable advice and encouragement throughout the study.

\section{References}

1) E. DodT: Experientia (Basel), 19, 642-643 (1963).

2) H. Breucker and E. HorstmanN: Prog. Brain Res., 10, 259-269 (1965).

3) A. OKSCHE and H. KirschsteIN: Z. Zellforsch., 78, 151-166 (1967).

4) C. Rüdeberg: Pub. Staz. Zool. Napoli, 35, 47-60 (1966).

5) C. RüDEBERG: Z. Zellforsch., 84, 219-237 (1968).

6) Y. Shiraishi and T. TAKedA: Bull. Fresh. Fish. Res. Lab., 11, 69-81 (1961).

7) I. HANYU: This Bull., 33, 255-261 (1967).

8) I. Hanyu, H. Niwa and T. Tamura: Vision Res., 9, 621-623 (1969).

9) Y. Omura and M. Oguri: This Bull., 35, 991-1000 (1969).

10) G. MrloniG: in "Fifth International Congress for Electron Microscopy", Vol. 2, p-8, Academic Press, New York and London (1963).

11) K. HAMA: J. Biophysic. and Biochem. Cytol., 7, 575-577 (1960).

12) H. D. Coulter: J. Ultrastruct. Res., 20, 346-355 (1967).

13) B. F. TRUMP: ibid., 5, 343-348 (1961).

14) M. L. WATSON: J. Biophysic. and Biochem. Cytol., 4, 475-478 (1958).

15) E. S. Reynol.ds: J. Cell Biol., 17, 208-212 (1963).

16) E. YamadA: Seitai no Kagaku, 18, 54-66 (1967).

17) S. E. G. Nilsson: J. Ultrastruct. Res., 11, 581-620 (1964).

18) K. HAMA: in "Fine Structure of Cells and Tissues" (E. Yamada et al. eds.), Vol. 4, 154-157, Igakushoin, Tokyo (1968).

19) L. MissotTen: in "The Structure of the Eyes" (J. M. RoHen ed.), Vol. 2, 17-28, Schattauer-Verlag, Stuttgt. (1965). 